\title{
PROVENANCE OF FLUVIAL AND DELTAIC SANDSTONES ACROSS THE PALEOCENE-EOCENE BOUNDARY, HANNA BASIN, WYOMING
}

XAVIER ROJAS NOGUEIRA, Temple University

Research Advisor: Jesse Thornburg

\section{INTRODUCTION}

South-central Wyoming's Hanna Basin contains many sandstone bodies deposited during to Paleocene through Eocene across the basin separated by periods finer grained lacustrine, overbank, and coal swamp deposition. These sandstone bodies were deposited primarily in fluvial and deltaic environments and contain sediment eroded of the surrounding upland regions (Wroblewski, 2002; Dechesne et al., in review). This study characterizes the relative mineralogical proportions of 25 Hanna Basin sandstone samples in order to improve interpretations of Hanna Basin paleo-drainage and possible climatic forcing during the Paleocene-Eocene Thermal Maximum, a major global warming event that occurred $56 \mathrm{Ma}$. Paleo-flow measurements were taken for the fluvial sandstone bodies to add context to the grain minerology data and more accurately associate sediment with potential upland sources.

\section{BACKGROUND}

\section{The Hanna Basin}

The Hanna Basin is a sedimentary basin in south central Wyoming (Fig. 1). It was formed during the Laramide Orogeny, which segmented the Sevier foreland basin of the United States into a series of intramontane basins during the latest Cretaceous into the Paleogene (Dickinson et al., 1988). Basementinvolved uplifts caused the flexural subsidence of the adjacent crust and generated accommodation space that was then filled by sediment eroded off the evolving mountain ranges (Dickinson et al., 1988; Weil et al., 2016). This history of unroofing

and uplift is recorded in provenance changes within alluvial strata in the adjacent sedimentary basins. The Hanna Basin preserves over 12,500 meters of Cambrian through Miocene sedimentary strata including anomalously thick Paleocene and Eocene strata of the Hanna Formation that reaches 3500 meters (Wroblewski, 2002). The age of the Hanna Formation is constrained by scattered mammal fossils, palynology, and $\mathrm{U}-\mathrm{Pb}$ detrital zircon geochronologic maximum depositional ages and is likely between $62 \mathrm{Ma}$ at the base and slightly younger than $54 \mathrm{Ma}$ at the top (Wroblewski, 2002 and references therein; Dechesne et al., in review). Strata varies across the

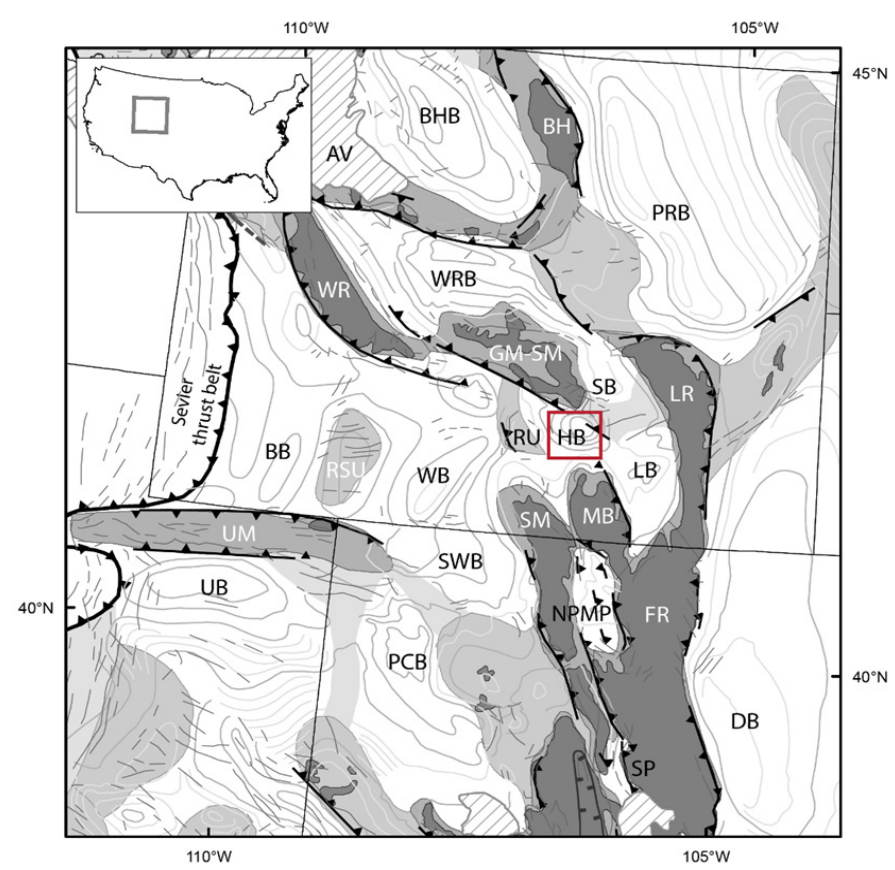

Figure 1. A regional geologic map showing the Hanna Basin relative to the surrounding upland areas and basins (Dechesne et al., in review). Important abbreviations include Hanna Basin (HB), Medicine Bow Mountains (MB), Sierra Madre Mountains (SM), Rock Springs Uplift (RSU), Granite Mountains-Seminoe Mountains (GM-SM), and Laramie Basin (LB). 
basin predominantly including, but not limited to, swampy coal beds, lacustrine siltstones, carbon rich overbank deposition, and fluvial and deltaic sandstone bodies (Lillegraven and Snoke, 1996; Secord, 1998; Wroblewski, 2002; Dechesne et al., in review). The sandstone bodies are commonly tabular or lenticular in form, and relatively resistant to weathering causing outcrops to protrude from the otherwise weathered fine-grained deposits.

\section{The Paleocene-Eocene Thermal Maximum}

The Paleocene-Eocene Thermal Maximum (PETM) was a geologically abrupt perturbation of the global carbon cycle and climate system that occurred 56 million years ago (McInerney \& Wing, 2011). Average annual temperatures were raised by $5-8^{\circ}$ for about $200 \mathrm{kyrs}$, a phenomenon that extensively affected the biosphere as well as atmospheric and oceanic circulation (McInerney \& Wing, 2011). The PETM is associated with a release of isotopically light carbon into the atmosphere and oceans and expressed as a significant negative carbon isotope excursion in both marine and nonmarine proxies, and has been investigated as a possible analog for modern anthropogenic climate change (McInerney, \& Wing, 2011). There are relatively few nonmarine stratigraphic sections wherein the PETM has been identified, but, where it has been identified there appear to be distinct fluvial responses. Specifically, researchers have observed an increase in fluvial channel-density, the size of fluvial sandbodies, river flow depths and widths, as well as an increase in the grain size of sediment transported by rivers during the PETM (Foreman et al., 2012; Foreman, 2014; Schmitz and Pujalte, 2007). Foreman et al. (2012) and Foreman and Rasmussen (2016) were able to constrain the provenance of sediment within the Piceance Creek Basin of northwest Colorado to isolate a climatic influence of river deposition, as well as characterize basin-scale paleodrainage conditions. This study represents a first step towards such an endeavor within the Hanna Basin of south-central Wyoming.

\section{METHODS}

In order to observe possible changes in provenance as recorded in sandstone minerology, we obtained 25 sandstone samples from sandbodies from over 1000 meters of stratigraphic section in the basin. These include samples from the basal fluvial sandbody through minor sandbodies overlying "Camp Channel", which is associated with Coal 86 and Coal 87 of Dobbin et al. (1929). Samples were selected to capture different ages and depositional environments within the basin. In the field, sample selection favored medium to coarse grained sandstones with little to no diagenetic features, each sample location was recorded with GPS. Samples were taken from the sand bodies representing Paleocene deposition $(\mathrm{n}=11)$, Eocene deposition $(\mathrm{n}=10)$, and four were taken from a multi-tiered sand body within a stratigraphic interval representing PETM deposition (Dechesne et al., in review). In addition, we included seventeen samples from large fluvial depositional environments, four deltaic samples, one marginal lacustrine channel sample, and three from a channelized deltaic environment. Thin sections were made from the sandstone samples, and we applied the Gazzi-
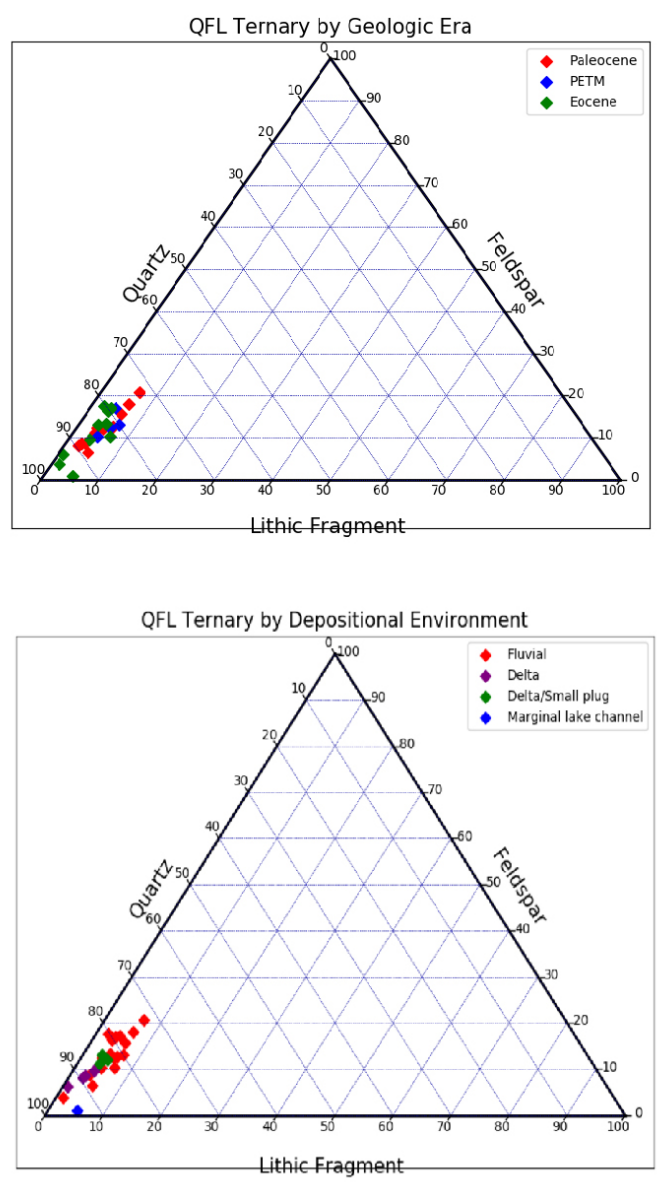

Figure 2. QFL Ternary plots showing the mineralogical proportions of the point counted sandstone samples sorted by age, depositional environment, and average paleo-flow direction. 
Dickinson method point counting 400 minerals per slide documenting the relative abundance of monoand poly-crystalline quartz, plagioclase, potassium feldspar, and lithic fragments (igneous, sedimentary, and metamorphic) as well as minor accessory minerals such as micas and minor amphiboles. The minerals were then grouped in accordance with the methodology applied by Dickinson (1970), with sedimentary, igneous, and metamorphic rock clasts categorized as lithics, poly- and mono-crystalline quartz clasts classified as Quartz and Plagioclase and Potassium Feldspar classified as Feldspar to plot each sample sorted by age and depositional environment into QFL ternary plots.

To supplement the mineralogical data, 284 paleo-flow measurements were taken from the fluvial deposited sandstone bodies by recording the strike and dip of unaltered trough cross bedding. The paleo-flow measurements for each horizontally continuous sand body were digitally averaged into a single azimuth, vector value.

\section{RESULTS}
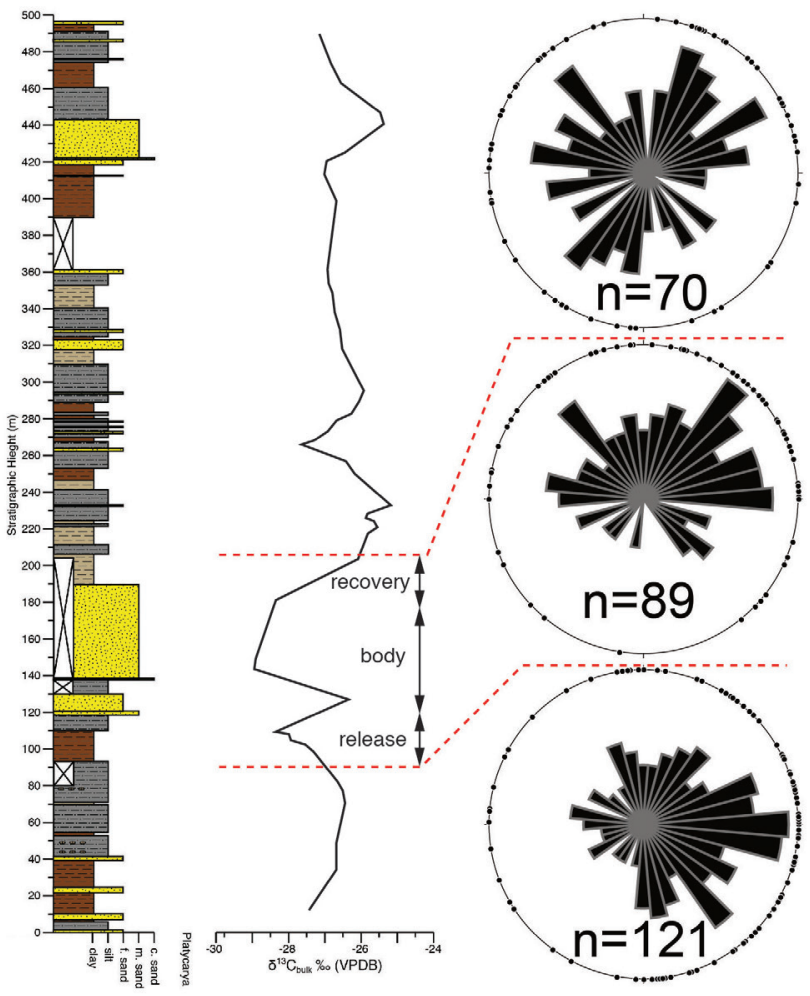

Figure 3. Paleocurrent rose diagrams spanning the PaleoceneEocene Thermal Maximum and accompanying stratigraphic section and carbon isotope record.

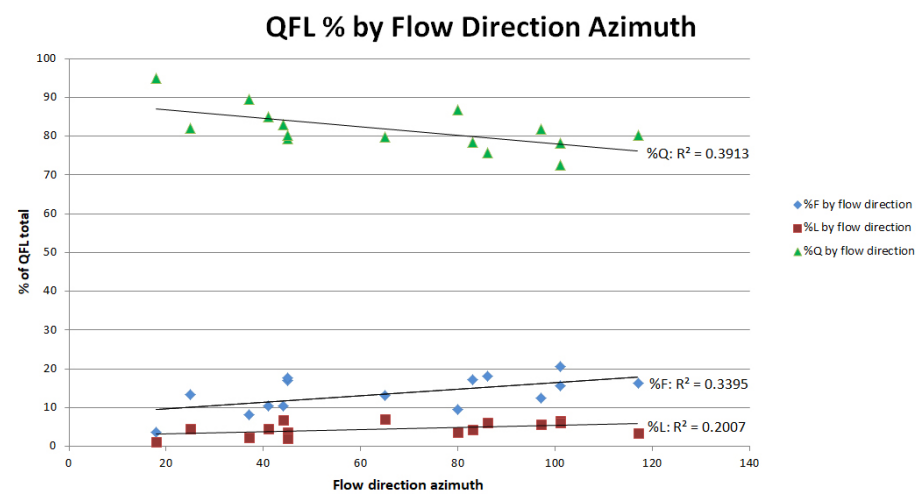

Figure 4. Linear regression of fluvially deposited sandstone samples' QFL proportions explained by the sand body average paleo-flow direction.

The descriptive statistics of the QFL proportion varied somewhat by age (Fig. 2; Table 1), but two tailed t-tests conducted comparing the means of Quartz, Feldspar, and Lithic percentages between the geologic eras (Paleocene, PETM, and Eocene) were unable to reject the null hypothesis that the compositions were drawn from the same underlying population at the 0.05 confidence level. Fluvial sandbodies tend to be richer in feldspars than deltaic deposits and marginal lacustrine sandstones (Fig. 2). Rose diagrams of paleocurrent directions (Fig. 3) show a range of directions with river flowing dominantly to the east in the Paleocene, to the north-northeast during the PETM, and to the northeast during the early Eocene (Fig. 3). However, the early Eocene directions are particularly variable and there are components of flow to the northwest and southwest (Fig. 3). For fluvial sandbodies that had both a thin section sample and paleocurrent measurements we were able to calculate a linear regression with the fluvial samples' QFL proportions plotted against the associated average flow direction azimuth (Fig. 4) produced $\mathrm{R}^{2}$ values of 0.39, 0.34 and, 0.24 for Quartz, Feldspar, and Lithic proportions respectively with the Feldspar proportion slightly rising with increased flow azimuth (more towards the South-East) at the expense of the Quartz proportion.

\section{DISCUSSION}

The QFL ternary diagrams, t-tests, and linear regressions allow the point counted mineralogy data to be interpreted basins larger geologic context. Depositional environment appears to be one factor 
affecting mineralogy with large fluvial deposits containing higher proportions of Feldspar clasts compared to deltaic, lacustrine, and small channel plug deposit. This finding is somewhat intuitive and could represent Feldspar's lower hardness affecting its transport durability causing distal deposits to be relatively poor in countable Feldspar clasts. The t-tests found no significant difference in the QFL proportions between deposits from the Paleocene, PETM, and Eocene, which supports rejecting the hypothesis that PETM related climatic forcing significantly changed the Hanna Basin drainage and sediment sourcing. This is a similar result to that observed in the Piceance Creek Basin of northwest Colorado spanning the PETM (Foreman et al., 2012; Foreman and Rasmussen, 2016). This implies that the proposed fluvial response of greater channel mobility and "flushing" of fine-grained sediment downstream did not cause any new source lithologies to be exposed in the hinterlands of these basins. Indeed any increases in erosion were not associated with unroofing sequences and may be related to greater reworking or transport of transiently stored sediment in alluvial systems versus greater erosion in hinterland. However, this hypothesis requires further testing.

Calculating linear regression for the QFL proportions (dependent variable) as controlled by average paleoflow azimuth of the fluvial sandstone body sampled (independent variable) indicates that average paleoflow azimuth may have some effect on the proportion of Feldspar and Quartz where fluvial deposits that flowed more to the southeast contain a higher Feldspar proportion than deposits with paleo-flows towards the northeast. This relationship between paleo-flow and mineralogy could be driven by the lithology differences between the active uplifts surrounding the Hanna Basin during the Paleocene-Eocene transition (Hajek et al., 2012; Wroblewski, 2002). The calcalkaline pluton of the Seminoe Mountains to the northeast could be the source of the more Feldspar rich sediment associated with the fluvial sand bodies with more southeast directed paleo-flows. The higher potentially higher Quartz proportions in the northeastern flowing fluvial deposits could have been sourced from the Medicine Bow or Sierra Madre mountains, which are to the south and southwest of the Hanna Basin respectively (Figure 1). Both uplifted regions contain exposed Proterozoic and Paleozoic granitic plutons as well as quartzite units that could supply the more Quartz rich sands.

\section{ACKNOWLEDGEMENTS}

This material is based upon work supported by the Keck Geology Consortium and the National Science Foundation under Grant No. 1659322. Special thanks to Brady Foreman, Ellen Currano, Jesse Thornburg, Regan Dunn, and Marieke Dechesne for the expertise and help along the way. I would also like to acknowledge my partner Anthony Semeraro for keeping me company during long days in the fields as well as the work and support of my peers Christine Shonnard, Jake Polsak, Keifer Nace, and James Chisholm.

\section{REFERENCES}

Dechesne, M., E.D. Currano, E. D., Dunn, R.E., Higgins, P., Hartman, J.H., Chamberlain, K.R., and Holm-Denoma, C.S., In review, Depositional patterns of the fluvial to paludal strata of the Hanna Formation across the Paleocene - Eocene boundary, Hanna Basin, Wyoming.

Dickinson, R.W. (1970). Interpreting detrital modes of greywacke and arkose, Journal of Sedimentary Petrology, 40(2), 695-707.

Dickinson, R.W., Klute, A.M., Hayes, J.M., Janecke, U.S., Lundin, R.E., et al. (1988).

Paleogeographic and paleotectonic setting of Laramide sedimentary basins in the central Rocky Mountain region, Geological Society of America Bulletin, 100, 1023-1039.

Dobbin, C. E., Bowen, C. F., Hoots, H. W. 1929. Geology and coal and oil resources of the Hanna and Carbons basins, Carbon County, Wyoming. U.S. Geological Survey Bulletin 804: $88 \mathrm{p}$.

Foreman, Z.B. (2014). Climate-driven generation of a fluvial sheet sand body at the PaleoceneEocene boundary in north-west Wyoming (USA), Basin Research, 26, 225-241. 
Foreman, B.Z., Rasmussen, D.M. (2016) Provenance signals in the Piceance Creek Basin: Unroofing of the Sawatch Range and extent of the early Paleogene California river system (Colorado, U.S.A.) Journal of Sedimentary Research 86: 1345-1358.

Foreman B., Clementz M.T., Heller P.L. 2012. Evaluation of paleoclimatic conditions east and west of the southern Canadian Cordillera in the mid-late Paleocene using bulk organic $\delta 13 \mathrm{C}$ records. Palaeogeography, Palaeoclimatology, Palaeoecology 376: 103-113.

Hajek. E. A., P.L. Heller, and E.L. Schur. (2012). Field test of autogenic control on alluvial stratigraphy (Ferris Formation, Upper Cretaceous-Paleogene, Wyoming), GSA Bulletin, 124(11/12), 18981912.

Lillegraven, J.A., Snoke, A.W. 1996. A new look at the Laramide orogeny in the Seminoe and Shirley mountains, Freezeout Hills, and Hanna Basin, south-central Wyoming. Wyoming State Geological Survey Public Information Circular no. $36,52 \mathrm{p}$.

McInerney, F. A. \& Wing, S. L. (2011). The Paleocene-Eocene Thermal Maximum: a perturbation of carbon cycle, climate, and biosphere with implications for the future. Annu. Rev. Earth Planet. Sci, 39, 489-516

Murphy, B. H., Farley, K. A., Zachos, J. C. (2010). An extraterrestrial $3 \mathrm{He}$-based timescale for the Paleocene-Eocene Thermal Maximum (PETM) from Walvis Ridge, IODP Site 1266. Geochim. Cosmochim. Acta, 74, 5098-5108.

Schmitz, B., Pujalte, V. 2007. Abrupt increase in seasonal extreme precipitation at the Paleocene-Eocene boundary. Geology 35: 215218.

Secord, R. 1998. Paleocene mammalian biostratigraphy of the Carbon Basin, southeastern Wyoming, and age constraints on local phases of tectonism. Rocky Mountain Geology 33:

$119-154$.
Weil, A. B., A. Yonkee, Schultz, M. (2016). Tectonic evolution of a Laramide transverse structural zone: Sweetwater Arch, south central Wyoming, Tectonics, 35, 1090-1120.

Wroblewski, A. (2002). The Role of the Hanna Basin in Revised Paleogeographic Reconstructions of the Western Interior Sea During the CretaceousTertiary Transition, Wyoming Geological Association Guidebook - 2002 Field Conference, Laramie, WY. 
